Correction

\title{
Correction: Surfleet, C., et al. Hydrologic Response of Meadow Restoration the First Year Following Removal of Encroached Conifers. Water 2019, 11, 428
}

\author{
Christopher Surfleet ${ }^{1, *} \mathbb{\infty}$, Thomas Sanford ${ }^{1}$, Gregory VanOosbree ${ }^{1}\left(\mathbb{C}\right.$ and John Jasbinsek ${ }^{2} \mathbb{C}$
}

1 Natural Resources Management and Environmental Science Department, California Polytechnic State University, San Luis Obispo, CA 93407, USA; thomas.sanford7@gmail.com (T.S.); gregvanoosbree@yahoo.com (G.V.)

2 Physics Department, California Polytechnic State University, San Luis Obispo, CA 93407, USA; jjasbins@calpoly.edu

* Correspondence: csurflee@calpoly.edu; Tel.: +1-805-756-2743

In the published article [1], the authors realized two errors: (1) Table 1 on page 3, the areas of the meadows were missing decimal points. The area of Marian Meadow is 18.2 ha and the Control Meadow area is 8.1 ha; and (2) on page 6 line 5, the pre-restoration dates are 2014-2015 WY.

The authors would like to apologize for any inconvenience caused to the readers by the change. The change does not affect the scientific results. The manuscript will be updated and the original will remain online on the article webpage, with a reference to this Correction.

\section{Reference}

1. Surfleet, C.; Sanford, T.; VanOosbree, G.; Jasbinsek, J. Hydrologic Response of Meadow Restoration the First Year Following Removal of Encroached Conifers. Water 2019, 11, 428. [CrossRef]

(C) 2020 by the authors. Licensee MDPI, Basel, Switzerland. This article is an open access article distributed under the terms and conditions of the Creative Commons Attribution (CC BY) license (http://creativecommons.org/licenses/by/4.0/). 